\title{
The Innate Immune Signaling System as a Regulator of Disease Resistance and Induced Systemic Resistance Activity Against Verticillium dahliae
}

\author{
Danai Gkizi, ${ }^{1}$ Silke Lehmann, ${ }^{2}$ Floriane L'Haridon, ${ }^{3}$ Mario Serrano, ${ }^{4}$ Epaminondas J. Paplomatas, ${ }^{1}$ \\ Jean-Pierre Métraux, ${ }^{3}$ and Sotirios E. Tjamos ${ }^{1}$ \\ ${ }^{1}$ Laboratory of Plant Pathology, Agricultural University of Athens, 75 lera Odos str., 11855 Athens, Greece; ${ }^{2}$ School of Life \\ Sciences, University of Warwick, Gibbet Hill, CV4 7AL Coventry, United Kingdom; ${ }^{3}$ Department of Biology, University of \\ Fribourg, 10 chemin du Musée, $\mathrm{CH}-1700$ Fribourg, Switzerland; and ${ }^{4}$ Centro de Ciencias Genómicas, Universidad Nacional \\ Autónoma de México, Av. Universidad 2001, 62210, Cuernavaca, Morelos, México
}

Submitted 25 November 2015. Accepted 13 January 2016.

In the last decades, the plant innate immune responses against pathogens have been extensively studied, while biocontrol interactions between soilborne fungal pathogens and their hosts have received much less attention. Treatment of Arabidopsis thaliana with the nonpathogenic bacterium Paenibacillus alvei K165 was shown previously to protect against Verticillium dahliae by triggering induced systemic resistance (ISR). In the present study, we evaluated the involvement of the innate immune response in the $\mathrm{K} 165$-mediated protection of Arabidopsis against $V$. dahliae. Tests with Arabidopsis mutants impaired in several regulators of the early steps of the innate immune responses, including fls 2 , efr-1, bak1-4, mpk3, mpk6, wrky22, and wrky29 showed that FLS2 and WRKY22 have a central role in the K165-triggered ISR, while EFR1, MPK3, and MPK6 are possible susceptibility factors for $V$. dahliae and bakl shows a tolerance phenomenon. The resistance induced by strain K165 is dependent on both salicylate and jasmonate-dependent defense pathways, as evidenced by an increased transient accumulation of $P R 1$ and $P D F 1.2$ transcripts in the aerial parts of infected plants treated with strain K165.

Verticillium dahliae Kleb. is a widely distributed soilborne pathogen causing vascular wilt on more than 160 plant species. It causes estimated billions of dollars in crop losses annually and worldwide (Pegg and Brady 2002). Colonization of the host plant by $V$. dahliae leads to leaf flaccidity, chlorosis and necrosis, stunting, vascular discoloration in stems, as well as flower and fruit reduction (Pegg 1981). The pathogen is difficult to control due to the long viability of the resting structures, the broad host range, and the inability of fungicides to affect the fungus once it enters the xylem (Fradin and Thomma 2006). The lack of efficacious pesticides and host resistance for the control of $V$. dahliae has stimulated efforts to develop alternative disease management strategies such as biocontrol agents (BCA).

Interestingly, Tjamos and associates (2004) reported the isolation of a plant growth-promoting rhizobacterium (PGPR),

Corresponding author: S. E. Tjamos; E-mail: sotiris@ aua.gr

*The $\boldsymbol{e}$-Xtra logo stands for "electronic extra" and indicates that one supplementary figure is published online.

() 2016 The American Phytopathological Society identified as Paenibacillus alvei K165, with biocontrol activity against $V$. dahliae in greenhouse and field experiments. The suppression of Verticillium disease by $P$. alvei K165 was attributed to induced systemic resistance (ISR) via the salicylic acid (SA)-dependent defense pathway (Tjamos et al. 2005). It is well-established that root colonization by PGPR can result in ISR via the SA or ethylene and jasmonate (ET/JA)dependent pathway that is accompanied by the accumulation of pathogenesis-related proteins (Iavicoli et al. 2003; Pieterse et al. 1998; Tjamos et al. 2005; Ton et al. 2002). However, little is known about the perception of the BCA by the plant and the cascade of the early signaling events that eventually lead to ISR.

The presence of pathogenic microorganisms is sensed by plants through perception of pathogen-associated molecular patterns (PAMPs) by pattern-recognition receptors (PRR) located mostly on the cell surface, leading to the PAMP-triggered immunity (Jones and Dangl 2006; Zipfel 2008). In Arabidopsis thaliana, the leucine-rich repeat receptor kinases (LRR-RK) flagellin-sensitive 2 (FLS2) and elongation factor Tu receptor (EFR) act as PRR for the bacterial PAMPs flagellin and elongation factor Tu (EF-Tu) (Gómez-Gómez and Boller 2000; Zipfel et al. 2006). Upon activation with their respective ligands, FLS2 and EFR form heteromeric complexes with the coreceptor BAK1 (Roux et al. 2011). This binding leads to the activation of a mitogen-activated protein kinase cascade, followed by the induction of defense genes, production of reactive oxygen species, callose deposition, and synthesis of SA (Asai et al. 2002; Schwessinger and Zipfel 2008).

Most of the data about bacterial perception by plants have been generated by studying the interaction of Pseudomonas syringae pv. tomato DC3000 with A. thaliana on leaves. The early events of pathogen or microbe perception have been less studied in roots (Millet et al. 2010). It will, therefore, be informative to investigate how PGPRs are perceived by roots and to determine the early signaling steps that lead to soilborne pathogen resistance.

In the present study, we investigated the biocontrol interaction of the $\mathrm{BCA} P$. alvei $\mathrm{K} 165$ against $V$. dahliae in A. thaliana. In particular, we examined the importance of the PAMP receptors FLS2 and EFR and the signaling cascades associated with these receptors, along with the expression of marker genes of the SA and ET/JA-dependent signaling pathways. 


\section{RESULTS}

FLS2 and WRKY22 are essential factors for the K165-triggered ISR, while EFR1, BAK1, MPK3, and MPK6 are possible susceptibility factors for $V$. dahliae.

The signaling pathway of K165-mediated induced resistance against $V$. dahliae was investigated using the $A$. thaliana mutants fls2, efr-1, bakl-4, mpk3, mpk6, wrky29, and wrky22, as inspired by the model, proposed by Asai and associates (2002), of an innate immune signaling cascade activated by bacterial LRR receptors in Arabidopsis.
Verticillium symptoms, mainly in the form of wilting, were rated in the different genotypes from 7 to 25 days postinoculation (dpi) (Figs. 1 and 2; Supplementary Fig. S1). Stunting (determined by length of the leaves) was also observed in the most susceptible genotypes (Col-0, wrky29, fls2, and wrky22); in those genotypes, the disease incidence was $100 \%$ at 25 dpi (data not shown).

The pathogenicity experiments revealed that the application of K165 conferred protection to Col-0 and wrky29, decreasing disease severity and, consequently, the overall amount of disease, referred to as area under the disease progress curve
A

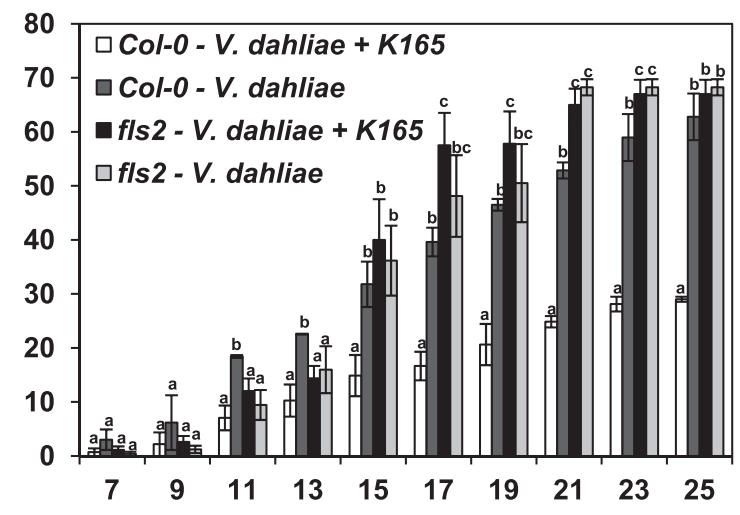

C

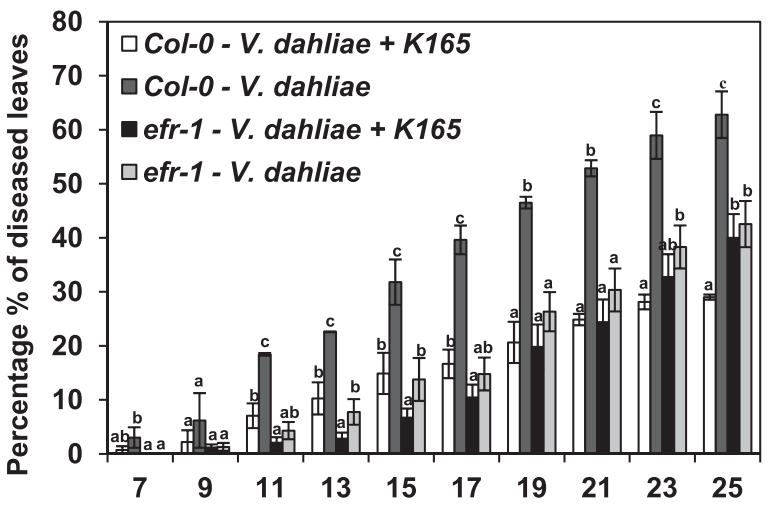

E

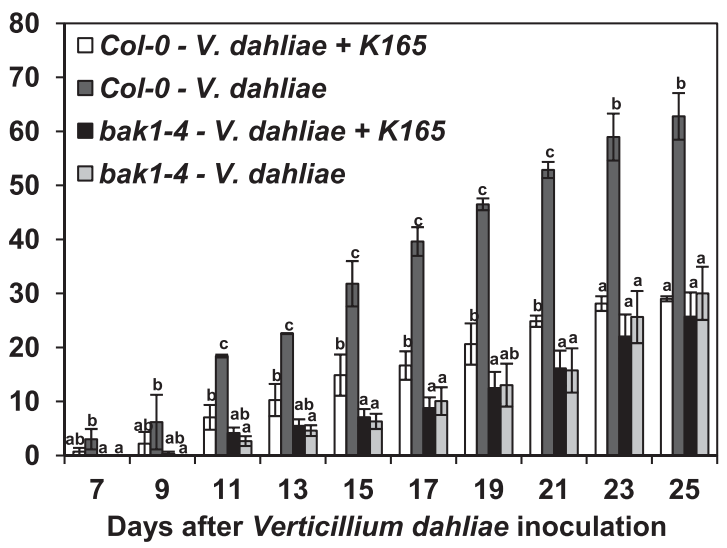

B

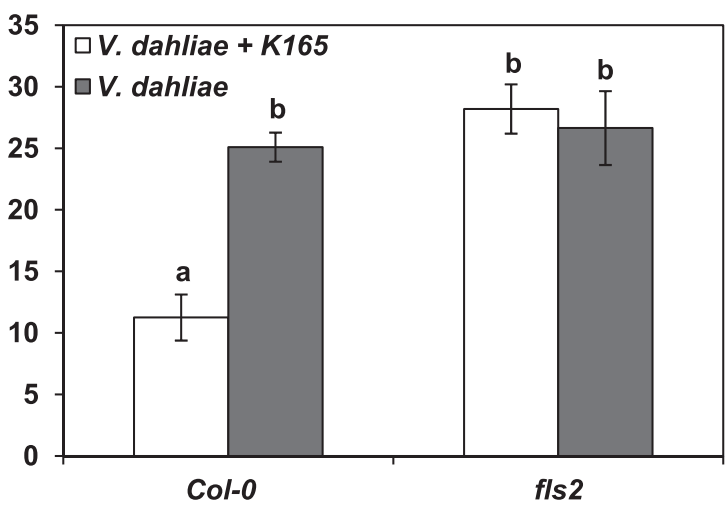

D

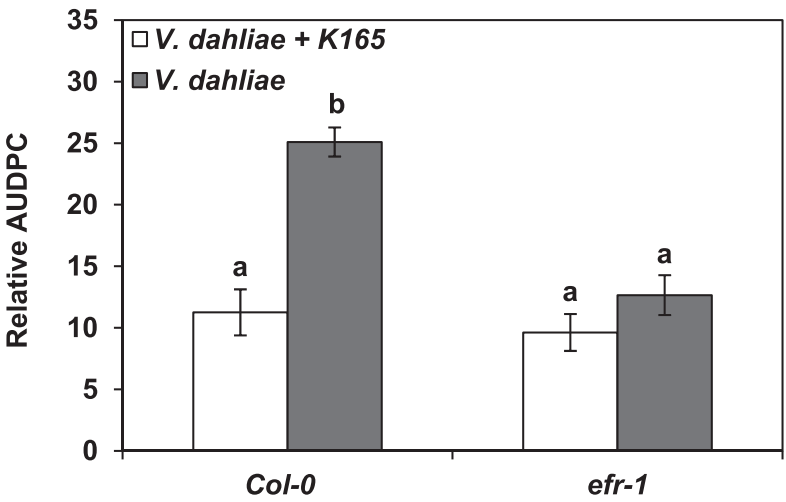

$\mathbf{F}$

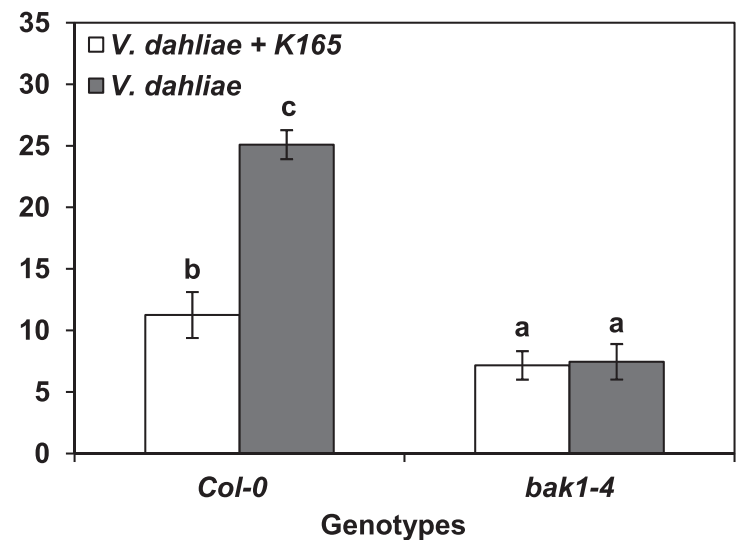

Fig. 1. Protection against Verticillium dahliae induced by Paenibacillus alvei K165 in the receptor and receptor-associated Arabidopsis mutants fls2, efr-1, and bak1-4, respectively, expressed as percentage of diseased leaves. A, C, and $\mathbf{E}$, At each disease rating day, columns with different letters are significantly different according to Tukey's multiple range test at $P<0.05$. B, $\mathbf{D}$, and $\mathbf{F}$, Results expressed as the relative area under the disease progress curve, i.e., the disease level as a percentage of the maximum possible area for the whole period of the experiment. The columns represent the means of 60 plants (two replications with 30 plants per replication and treatment) and the vertical bars indicate standard errors. Columns with different letters are significantly different according to Tukey's multiple range test at $P<0.05$. 
(AUDPC) (Fig. 2G and H). Thus, protection appears to be independent of WRKY29.

On the other hand, the application of K165 did not reduce Verticillium symptom development in fls 2 and wrky 22 compared with the corresponding controls (Figs. 1A and B and 2E and F). Therefore, functional FLS2 and WRKY22 are required for the development of K165-mediated protection.
The application of K165 did not decrease the percentage of disease severity in efr-1, bak1-4, mpk3, and mpk6 mutants (Figs. 1C, D, E, and F and 2A, B, C, and D). However, EFR, BAK1, MPK3, and MPK6 are unlikely to participate in the K165-triggered plant defense mechanism, since significantly lower AUDPC values were obtained for Verticillium wilt symptoms in the control ( $V$. dahliae-treated plants) efr-1,

B

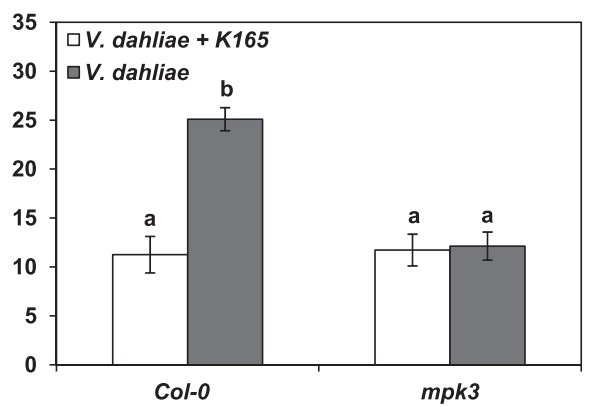

D

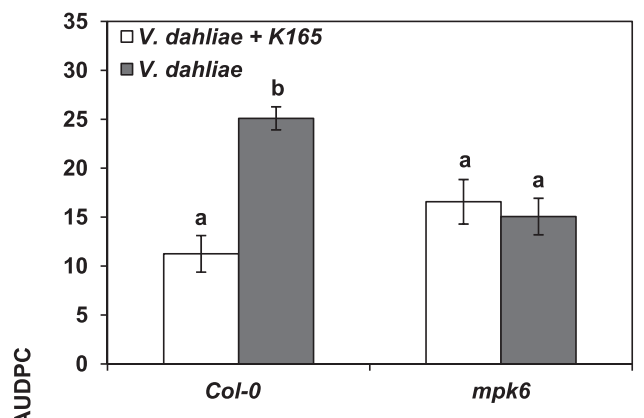

E

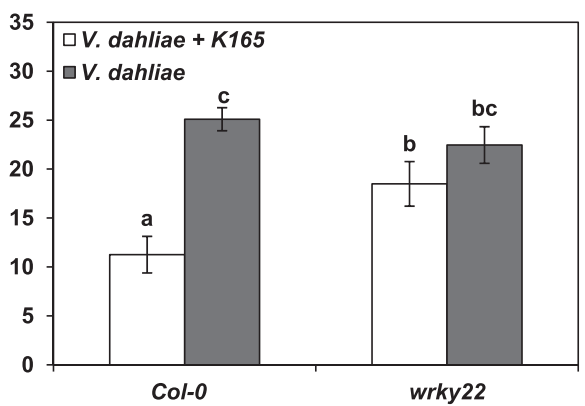

H

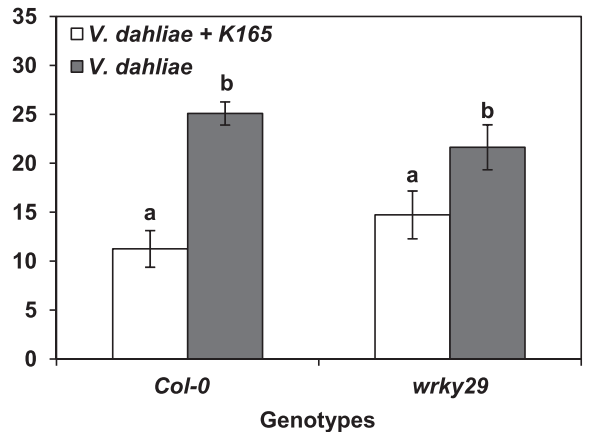

Fig. 2. Protection against Verticillium dahliae induced by Paenibacillus alvei K165 in the pattern-recognition receptor-driven defense signaling pathway Arabidopsis mutants $m p k 3, m p k 6$, wrky22, and wrky29, expressed as percentage of diseased leaves. A, $\mathbf{C}, \mathbf{E}$, and $\mathbf{G}$, At each disease rating day, columns with different letters are significantly different according to Tukey's multiple range test at $P<0.05$. B, D, $\mathbf{F}$, and $\mathbf{H}$, Results expressed as the relative area under the disease progress curve, i.e., the disease level as a percentage of the maximum possible area for the whole period of the experiment. The columns represent the means of 60 plants (two replications with 30 plants per replication and treatment) and the vertical bars indicate standard errors. Columns with different letters are significantly different according to Tukey's multiple range test at $P<0.05$. 
bak1-4, mpk3, and mpk6 mutants compared with the Col0 controls (Figs. 1C, D, E, and F and 2A, B, C, and D). This partial resistance indicates a hitherto unsuspected role of EFR, BAK1, MPK3, and MPK6 in the interaction of $V$. dahliae with the host plant. efrl, mpk3, and mpk6 are partially resistant to Verticillium disease, whereas bak1 is tolerant.

Are the recorded wilt symptoms really reflecting $V$. dahliae growth and colonization in vascular tissues? To approach this question, the level of fungal colonization was assessed in each

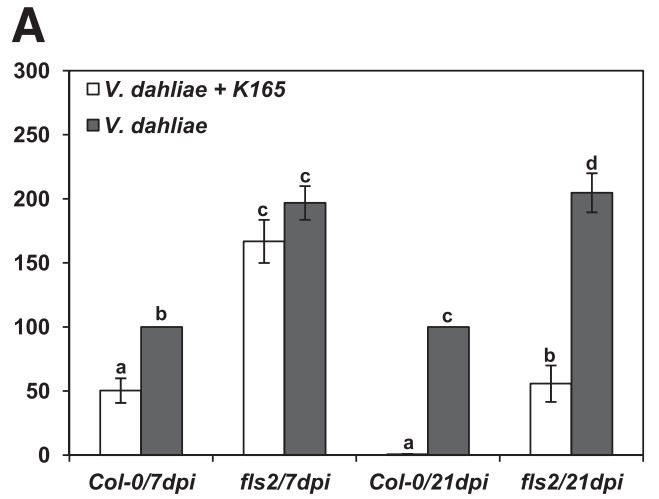

B
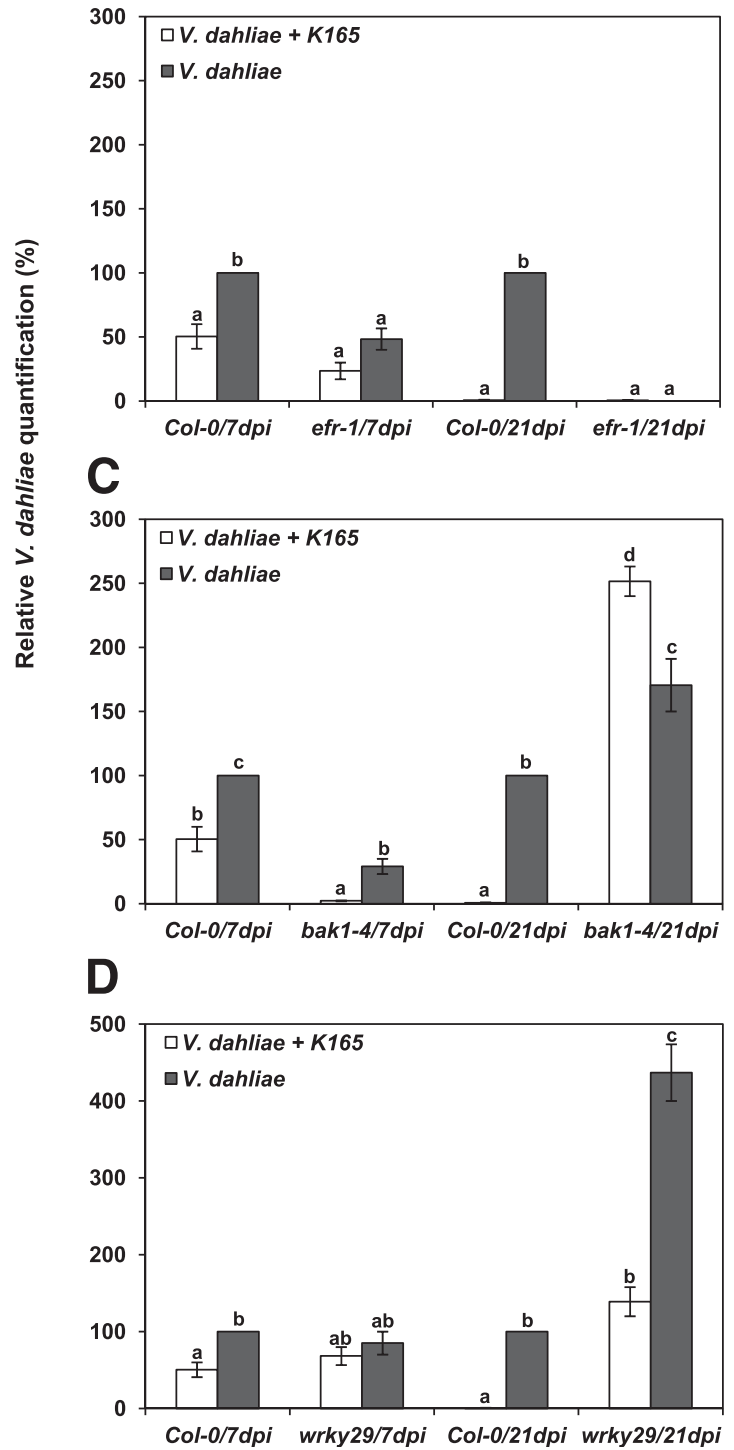

E

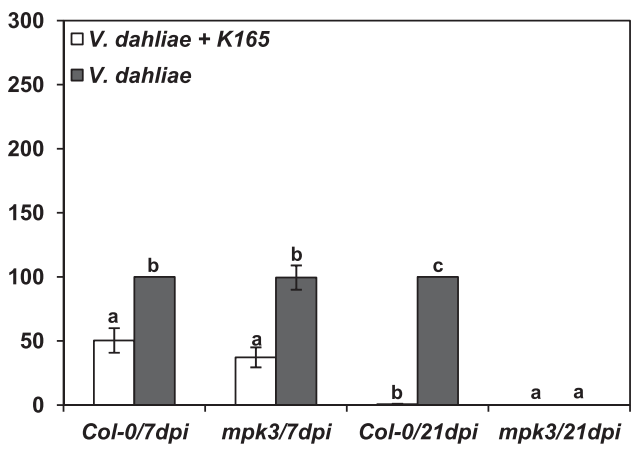

E

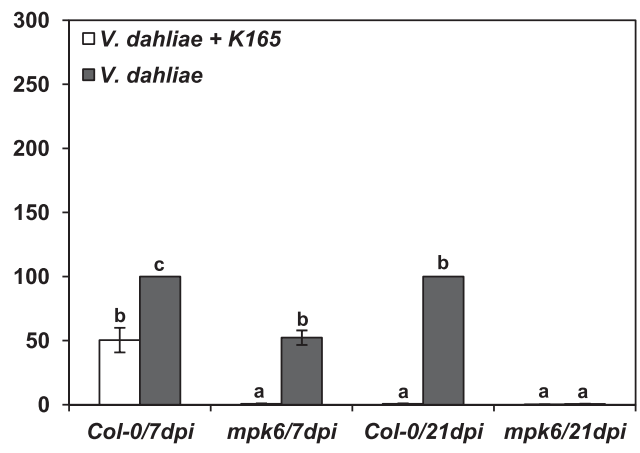

G

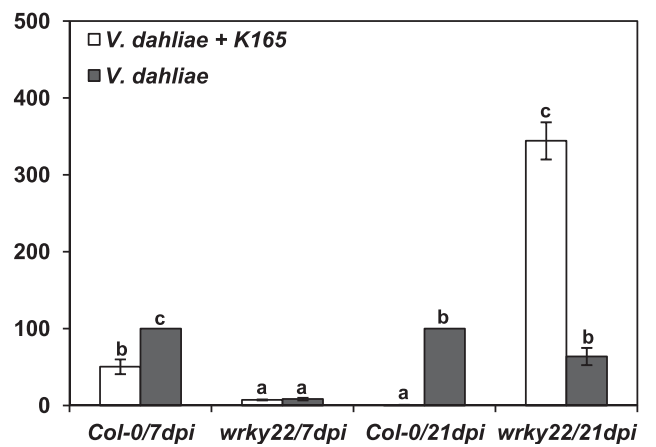

Fig. 3. Relative quantification of the Verticillium dahliae DNA levels in the Arabidopsis mutants fls2, efr-1, bak1-4, mpk3, mpk6, wrky22, wrky29, and wildtype Col-0 plants. Fungal DNA levels were estimated by quantitative polymerase chain reaction using total DNA isolated from the aerial parts of plants at 7 and 21 days postinoculation (dpi). The columns represent the means of two biological repeats (with 10 plants per treatment and repeat) and three technical repeats per biological repeat (total of six reactions per treatment). The vertical bars indicate the standard errors. Col-0 is set to $100 \%$. Columns with different letters are significantly different according to Tukey's multiple range test at $P<0.05$. 
genotype and treatment by real-time quantitative polymerase chain reaction (qPCR) at early (7 dpi) and late stages ( $25 \mathrm{dpi})$ of the disease.

Col-0 plants treated with K165 displayed a marked reduction of relative DNA levels of $V$. dahliae compared with untreated controls at both time points (Fig. 3). Therefore, the protective activity of K165 against $V$. dahliae is based on the activation of plant resistance rather than tolerance mechanisms, since tolerance does not limit infection but, instead, reduces or offsets its negative consequences on fitness (Horns and Hood 2012). The fls2 mutants exhibited high relative levels of $V$. dahliae DNA in agreement with the observed disease severity recordings at both time points, in contrast to efr- 1 , in which lower levels of the pathogen were observed relative to Col-0 (Fig. 3A and B). A decoupling between Verticillium wilt symptoms and relative quantification of pathogen DNA was observed in bakl-4, in which the DNA levels increased substantially with time in contrast to the AUDPC values (Figs. 1E and $\mathrm{F}$ and 3C). The situation in bakl-4 suggests a tolerance phenomenon.

On the other hand, the relative quantification of $V$. dahliae in $m p k 3$ and $m p k 6$ indicates partial resistance; since, in $m p k 3$ and $m p k 6$, the relative levels of Verticillium DNA were significantly lower than in Col-0 at $21 \mathrm{dpi}$ (Fig. 3E and F). In mpk6, the detected levels of pathogen were significantly lower than in Col-0 at both sampling time points, while in $m p k 3$ the reduction compared with Col-0 was only visible at $21 \mathrm{dpi}$.

In wrky22, qPCR analysis revealed an increase in the relative amount of the pathogen with time, especially in the case of the K165-treated plants, reflecting the susceptibility of wrky22 to the pathogen and the loss of the K165-mediated plant protection (Figs. 2E and $\mathrm{F}$ and $3 \mathrm{G}$ ). Likewise, in the case of the $V$. dahliae-treated wrky29, the results of the qPCR showed a considerable increase of the relative levels of $V$. dahliae DNA with time (Fig. 3D). In agreement with the pathogenicity experiments, the K165-treated wrky29 exhibited lower levels of pathogen DNA than the control plants ( $V$. dahliae-treated wrky29), confirming that WRKY29 is not required in the K165triggered ISR (Fig. 3D).

\section{The rhizosphere population of K165 in the different genotypes does not influence the disease outcome.}

To investigate whether the disease outcome in the K165treated fls2, efr-1, bakl-4, mpk3, mpk6, and wrky22 mutants was caused by insufficient colonization of the rhizosphere by strain K165, we determined the titer of the rifampicin-resistant K165 bacteria at 10 and 20 days after their application.

At $10 \mathrm{dpi}$, the highest K165 populations were recorded in wrky 22, fls2, and Col-0 (Fig. 4). The finding that wrky 22 and fls2 were colonized as much as the Col-0 shows that the rhizosphere population of K165 does not influence the disease outcome since, despite its high rhizosphere population, K165 was unable to protect wrky 22 and $f l s 2$ against $V$. dahliae. This idea is also supported by the K165 titers recorded at 20 dpi, when the K165 population in wrky22 ranged between those of wrky 29 and Col-0, both of which were genotypes protected by K165.

\section{K165-triggered ISR occurs in aerial tissues, possibly through both SA- and ET/JA-dependent defense pathways.}

The expression of $P R 1, P R 2$, and $P D F 1.2$, marker genes for the SA- and ET/JA-associated defense mechanisms, was analyzed by qPCR in K165-treated and V. dahliae-infected Col-0 plants, both in root and in aerial tissues sampled at 3, 7, and 14 dpi.

The most significant changes in transcript levels of $P R 1$, $P R 2$, and PDF1.2 were observed in the aerial tissues of the K165/V. dahliae-treated plants (Fig. 5B, D, and F). Interestingly, the expression of the monitored genes was suppressed in the aerial tissues of the $V$. dahliae-treated plants at the early infection stage of 3 dpi (Fig. 5 B, D, and F). On the other hand, the pathogen-inoculated K165-treated plants exhibited the highest $P R 1$ and $P D F 1.2$ transcript levels between treatments at all sampling points (Fig. 5B, D, and F). The single application of $\mathrm{K} 165$ also resulted in the upregulation of $P R 1, P R 2$, and PDF1.2 at all sampling points (Fig. 5B, D, and F).

In roots, the only significant differences in gene expression between treatments were observed for $P R 1$ and $P R 2$ at $14 \mathrm{dpi}$ (Fig. 5A, C, and E). Therefore, a more significant role is suggested for the aerial than the root tissues for the deployment of the K165-triggered ISR upon V. dahliae invasion.

\section{DISCUSSION}

In the last decades a number of studies have been devoted to plant-pathogen recognition events and the downstream signaling pathways leading to disease resistance or susceptibility. However, early recognition of BCA that trigger ISR and the subsequent signaling cascade are poorly described. Similarly, the importance of receptor-like kinases such as FLS2 and EFR and of the downstream signaling components in response to rootinvading pathogens is unknown. In the present study, mutants blocked at various steps in the defense-signaling cascade revealed that EFR, MPK3, and MPK6 seem to be susceptibility factors for Verticillium disease, while K165-mediated ISR against $V$. dahliae depends on FLS2 and WRKY22.

The partial resistance of efr- 1 and, therefore, the interplay of the EFR receptor with the pathogenicity mechanism of $V$. dahliae is an intriguing finding, since EFR binds specifically to the ubiquitous bacterial protein EF-Tu (Gómez-Gómez and Boller 2000; Zipfel et al. 2006). Interestingly, V. dahliae possesses a gene (VDAG_01458.1) homologous to EF-Tu that might interfere with EFR and could possibly promote disease, although this would have to be studied further. It is also known that ET modulates EFR-triggered immunity (Tintor et al. 2013). In parallel, the ET receptor ETR1 is a susceptibility factor for $V$. dahliae and V. longisporum (Johansson et al. 2006; Pantelides et al. 2010). Thus, it is tempting to speculate from those observations that Verticillium takes advantage of components of EFRregulated immunity to infect the plant.

The fls 2 plants were as susceptible to Verticillium disease as the wild types and K165-mediated ISR against $V$. dahliae was compromised in $f l s 2$ (Fig. 1A and B). It is evident that FLS2 has a central role in the recognition of K165 and the triggering of the downstream signaling cascade, as in the interaction of Arabidopsis with Pseudomonas syringae pv. tomato (Asai et al.

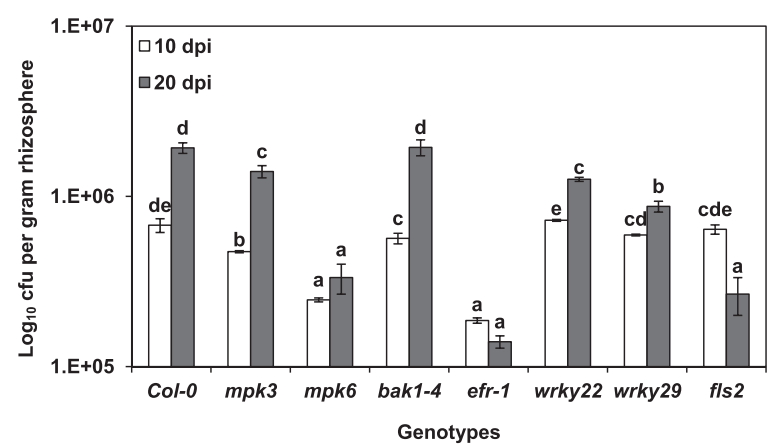

Fig. 4. Titer of Paenibacillus alvei K165 in the rhizosphere of Arabidopsis thaliana Col-0 plants and mpk3, mpk6, bak1-4, efr-1, wrky22, wrky29, and fls 2 mutants, at 10 and 20 days postinoculation (dpi). The vertical bars indicate standard errors. At each sampling day, columns with different letters are significantly different according to Tukey's multiple range test at $P<0.05$. 
2002). The presence of an amino acid sequence (EKLSSGYRINRAADDAAGLAI) with $67 \%$ homology to flg22 (QRLSTGSRINSAKDDAAGLQIA) translated from the WP021258858 locus of the $P$. alvei species (taxid: 44250) suggests a direct interaction of FLS2 with the flagellin subunit of K165. Is this interaction the trigger for the K165-mediated ISR? In previous studies, it has been shown that treatment with flg22 leads to the accumulation of SA and that FLS2 is dynamically regulated by SA (Mishina and Zeier 2007; Tateda et al. 2014; Tsuda et al. 2008). FLS2 might, indeed, be the crucial receptor in the K165-mediated protection of the plant since K165-triggered ISR is SA-dependent (Tjamos et al. 2005).

Like other PRR, the FLS2 and EFR receptors require BAK1 for function. BAK1 does not have a direct role in elicitor perception but seems to form heteromeric complexes with
FLS2 and EFR after microbe-associated molecular pattern (MAMP) detection (Chinchilla et al. 2007; Heese et al. 2007; Schulze et al. 2010). Accumulating experimental evidence points to BAK1 as a central regulator of plant immunity and a target of several effectors of pathogen virulence (Fradin et al. 2011; Shan et al. 2008). In a previous study, Fradin and associates (2011) reported that bakl-4 shows enhanced susceptibility to $V$. dahliae, as documented by a higher pathogen level in the aerial tissues of bakl-4 than Col-0 at $21 \mathrm{dpi}$; similar results were also obtained in the present study (Fig. 3C). However, symptom development as well as the relative AUDPC values were much lower in bakl-4 than in Col-0 (Fig. 1E and F). These results suggest the existence of a tolerance mechanism in bak1-4. In a pioneering study on molecular quantification of Verticillium disease in a tolerant tomato cultivar, it has been
A

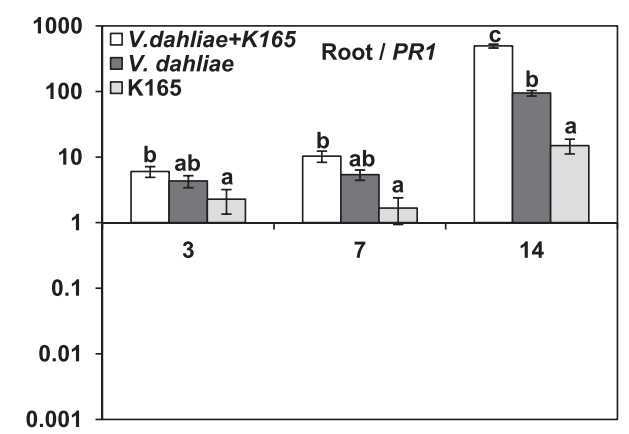

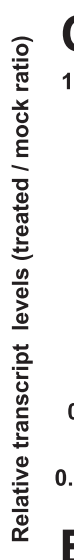

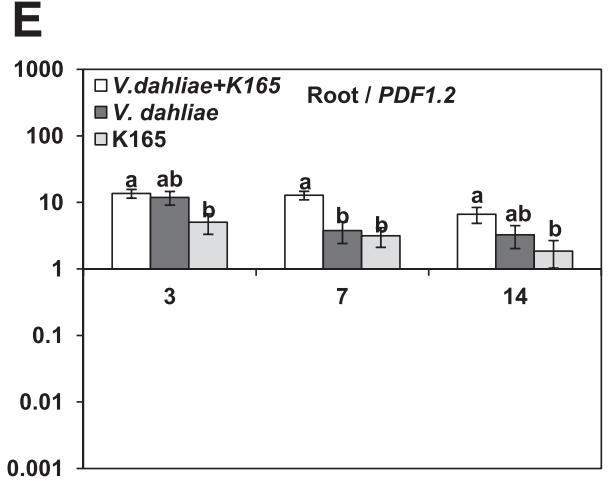

B

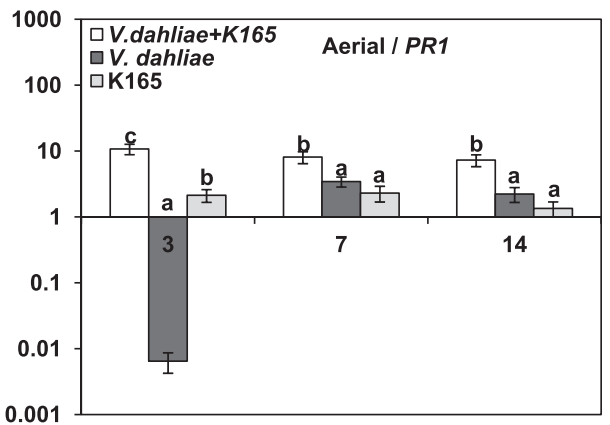

D

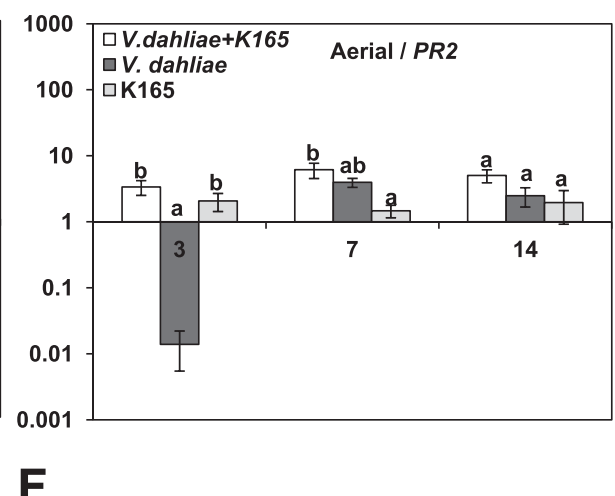

$\mathbf{F}$

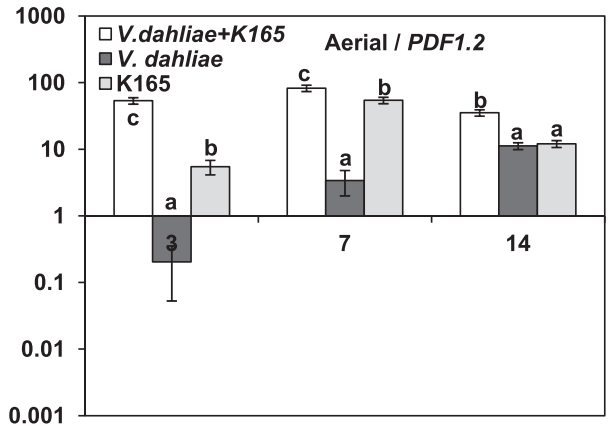

Days after $V$. dahliae inoculation

Fig. 5. A and B, Relative transcript levels of PR1, $\mathbf{C}$ and D, PR2, and $\mathbf{E}$ and $\mathbf{F}, P D F 1.2$ in the root (A, C, E) and aerial tissues (B, D, F) of Arabidopsis Col-0 plants in response to infection with Verticillium dahliae or treatment with Paenibacillus alvei K165. Total RNA was isolated from plants at 3, 7 , and 14 days postinoculation, was converted to cDNA, and was used as template in quantitative polymerase chain reaction assays. Transcript levels of the examined genes were normalized to the expression of At $4 \mathrm{~g} 26410$ measured in the same samples and were expressed relative to the normalized transcript levels in mock-treated plants. The columns represent the means of three biological repeats (with 10 plants per treatment and repeat) and three technical repeats per biological repeat (total of nine reactions per treatment). The vertical bars indicate the standard errors. Columns with different letters are significantly different according to Tukey's multiple range test at $P<0.05$. 
concluded that, in a tolerant host, an active coating response traps the pathogen as effectively as in a resistant plant, but the amounts of the pathogen remain higher than in resistant plants, suggesting that fungal sporulation and lysis are either delayed in the tolerant interactions or do not occur (Chen et al. 2004). The pathogen is controlled rather than eliminated in the resistant plants, according to different studies (Chen et al. 2004; Heinz et al. 1998; Veronese et al. 2003). A plausible explanation about the tolerance of bakl-4 to V. dahliae could lie on the positive role of brassinosteroids (BR) in ET biosynthesis (Arteca 1995; Joo et al. 2006). BAK1 serves as an enhancer of BR signaling affecting the feedback regulation of BR biosynthesis (Wang et al. 2008; Yun et al. 2009) and, consequently, the effect of BR on ET biosynthesis. ET has been long-associated with Verticillium wilt symptoms, as the main contributing factor for the symptoms of epinasty and wilting (Cronshaw and Pegg 1976; Pegg 1976). Along these lines, Robison and associates (2001) examined the effects of reduced ET synthesis on Verticillium wilt of tomato by transforming tomato with 1-aminocyclopropane1-carboxylate (ACC) deaminase, which cleaves ACC, the immediate biosynthetic precursor of ET in plants. It was observed that reduced ET synthesis results in increased disease tolerance.

ET might also explain the Verticillium resistance of $m p k 3$ and mpk6. In Arabidopsis, it has been demonstrated that ACS2 and ACS6 are substrates of MPK3 and MPK6 (Han et al. 2010; Liu and Zhang 2004). Phosphorylation of ACS2/ACS6 by MPK3 and MPK6 stabilizes the ACC synthase (ACS) protein in vivo, resulting in increases in cellular ACS activity and in ET production. Interestingly, MPK3 and MPK6 not only function in the phosphorylation-induced stabilization of ACS2/ACS6 proteins but also signal the ACS2 and ACS6 gene activation after Botrytis cinerea infection (Li et al. 2012). As proposed earlier, ET synthesis and perception might have a significant role in Verticillium pathogenesis and plant resistance or tolerance (Robb et al. 2007).

In contrast, wrky 22 and wrky 29 were highly infected by Verticillium spp. compared with the resistance observed in mpk3 and mpk6. Notably the V. dahliae-treated wrky29 and the K165-treated wrky 22 harbored the highest pathogen levels among all the tested genotypes. In the case of K165-treated $w r k y 22$, the high endophytic amounts of the pathogen reflect the participation of WRKY22 in the K165-mediated ISR. WRKY22 regulates innate immunity genes, defense genes, and PRR-related genes (Hsu et al. 2013) and its activation is induced by flg22 and $N$-acyl-homoserine lactones (AHL) (Schikora et al. 2011). AHL are involved in bacterial quorum sensing. Several reports have also provided indirect evidences that AHL play a role in plant immunity (Pang et al. 2009; Schuhegger et al. 2006); however, the molecular basis of the effect of AHL on the plant immune system remains unknown. The findings of the present study suggest a crucial role for WRKY22 in K165-triggered ISR and further studies are needed to elucidate whether WRKY22 is activated solely upon perception from K165-derived flagellin or by other compounds such as AHL.

The observed decoupling between disease severity and the estimated relative quantity of the pathogen observed in some treatments (V. dahliae-treated fls 2 at $21 \mathrm{dpi}$ and wrky 29 at $21 \mathrm{dpi}$; $\mathrm{K} 165+$ V. dahliae-treated wrky 29 at $21 \mathrm{dpi}$ and $w r k y 22$ at $21 \mathrm{dpi}$ ) can be attributed to the cyclical periods of fungal elimination that characterize the lifestyle of $V$. dahliae in the vascular system of plants such as tomato and oilseed rape (Chen et al. 2004; Eynck et al. 2007; Heinz et al. 1998). Also, the levels of DNA of the pathogen reflect numbers of propagules more than actual biomass; spores are small, relative to mycelial cells, but have the same DNA content (Chen et al. 2004). This disparity between pathogen proliferation and symptom development has also been observed in bacterial (Bent et al. 1992; Lund et al. 1998; O'Donnell et al. 2001) and viral (Cecchini et al. 2002) plantpathogen interactions, and it has been partly explained by the possibility that symptoms can result from pathogen-induced signals that cause changes in normal plant growth and development (Cecchini et al. 2002; Dietrich et al. 1994; Lund et al. 1998; O'Donnell et al. 2001; Pilloff et al. 2002). It is evident that, in vascular wilts in which phytohormones, such as ET, are involved in the development of disease symptoms, both symptoms and pathogen quantification need to be measured to draw reliable conclusions about resistance, tolerance, or susceptibility.

It has been long-stated that, for Verticillium-caused wilt diseases, the resistance or susceptibility of the host plant is generally considered to be determined mainly by the cellular interactions between the plant and the fungus occurring in the stem (Robb et al. 2007). The present study also showed most striking differences in the expression of $P R 1, P R 2$, and $P D F 1.2$ between treatments in the aerial tissues after K165 and $V$. dahliae treatment or $V$. dahliae treatment of Col-0 plants. The strong activation of defense-associated genes observed after pathogen inoculation of K165-treated plants suggests the existence of a priming mechanism. Interestingly, the application of K165 induced the expression of markers for SA $(P R 1$ and $P R 2)$ and ET/JA ( $P D F 1.2)$ signaling pathways. The upregulation of $P R 1$ in the aerial parts of the K165- and V. dahliae-treated plants can be crucial for restricting the pathogen at the early infection stages, when $V$. dahliae follows a biotrophic life style (Thaler et al. 2004). The importance of PRl during the biotrophic stages of plant infection by $V$. dahliae has also been proposed by Zhang and associates (2013). In addition, a previous study has already highlighted the significance of the SA-dependent defense pathway in the K165-mediated ISR against $V$. dahliae (Tjamos et al. 2005). The triggering of the PDF1.2 expression by K165 is consistent with the data showing that PGPR-primed plants often display JA-dependent defense responses upon pathogen invasion (Pieterse et al. 1998; Pozo et al. 2008; van Hulten et al. 2006). However, since JA-related mutants did not show changes in disease severity caused by $V$. dahliae or V. longisporum, JA-signaling might be of less importance in the presently studied system (Johansson et al. 2006; Pantelides et al. 2010; Veronese et al. 2003). JA/ET-mediated defense responses are considered as more effective against necrotrophic than biotrophic pathogens (Glazebrook 2005) and, although most reports indicate a mutually antagonistic interaction between SA- and JA-dependent signaling, synergistic interactions have been described as well (Mur et al. 2006). Therefore, we cannot completely exclude a role for the JA pathway in the K165-mediated plant protection, especially at the later necrotrophic stages of the disease.

Furthermore, the qPCR analysis revealed that $V$. dahliae suppressed the plant immune system, since the expression of $P R l$, $P R 2$, and PDF1.2 was downregulated in the aerial tissues of the $V$. dahliae-treated plants at the early infection stages $(3 \mathrm{dpi})$. Similarly, a substantial suppression of $P A L$ mRNA levels occurred after inoculation of a tomato line susceptible to Verticillium alboatrum, while the suppression was absent or substantially reduced in a resistant line (Lee et al. 1992). The suppression of the immune system and, mainly, the SA-dependent defenses could be a strategy of $V$. dahliae to promote disease, since it would allow the pathogen to overcome the plant defense responses during its initial biotrophic stage. The use of EFR1, MPK3, and MPK6 as susceptibility factors from $V$. dahliae highlights the interplay of the pathogen with the plant defense signaling pathway.

In summary, this study shows the involvement of FLS2 and WRKY22 in a BCA-mediated ISR in A. thaliana (Fig. 6). The results also suggest that EFR, MPK3, and MPK6 are 
susceptibility factors for V. dahliae (Fig. 7) and help promote disease development.

\section{MATERIALS AND METHODS}

\section{Fungal culture.}

V. dahliae isolated from Raphanus sativus L. (provided by E. Ligoxygakis, National Agricultural Research Institute, Crete, Greece), with known pathogenicity against $A$. thaliana plants (Tjamos et al. 2005), was used in the experiments. The fungal strain was cryopreserved by freezing a conidial suspension in $25 \%$ aqueous glycerol at $-80^{\circ} \mathrm{C}$ (Maniatis et al. 1982). Before being used, the fungus was transferred to potato dextrose agar (Merck, Darmstadt, Germany) at $24^{\circ} \mathrm{C}$ for 5 days. For the bioassays, a suspension of $10^{7}$ conidia of distilled sterile water per milliliter was prepared from a culture grown for 5 days at $24^{\circ} \mathrm{C}$ in sucrose sodium nitrate liquid medium (Sinha and Wood 1968).

\section{Bacterial culture.}

A K165 rifampicin-resistant mutant (Tjamos et al. 2004) was used throughout the experiments. The K165 strain was cryopreserved by freezing a $1 \times 10^{8} \mathrm{CFU} / \mathrm{ml}$ suspension in $25 \%$ aqueous glycerol at $-80^{\circ} \mathrm{C}$ (Maniatis et al. 1982). Before being used, K165 was transferred to nutrient broth agar plus glycerol (NAG) at $28^{\circ} \mathrm{C}$ for 2 days. For the bioassays, bacterial cells were prepared in nutrient broth plus glycerol in an orbital incubator

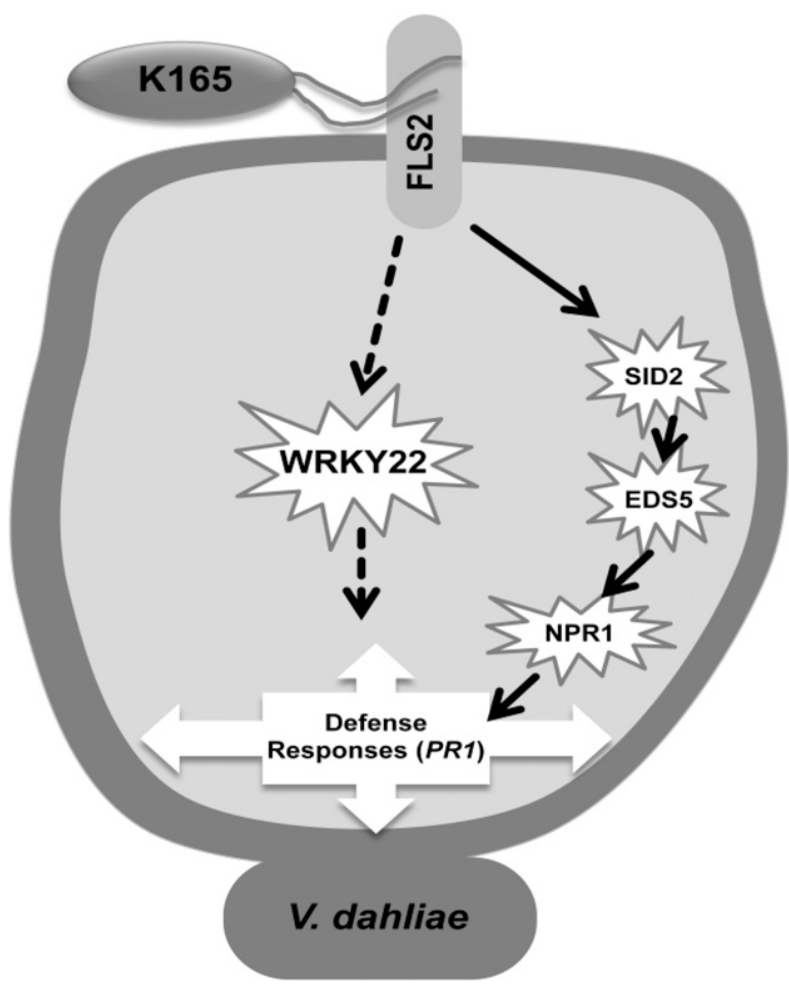

Fig. 6. Proposed model for the Paenibacillus alvei K165 induced systemic resistance signaling pathway leading to plant protection against Verticillium dahliae. K165 is perceived by the FLS2 receptor, leading to increased PRI transcripts in the aerial plant parts. The loss of the K165 protective activity in wrky22 suggests the participation of the WRKY22 transcription factor in the K165-triggered signaling cascade. In a previous study, the suppression of $V$. dahliae by $P$. alvei K165 was attributed to the induction of systemic resistance via the salicylic acid (SA)-dependent defense pathway (Tjamos et al. 2005). It is known that flg 22 treatment results to SA accumulation, so the FLS2 binding with K165 flagellin subunit may trigger the SAdependent plant defense mechanism. Dashed lines represent the results of this study, whereas solid lines represent the results of Tjamos and associates (2005) and the presumed connection between FLS2 and the SA-dependent defense. at $180 \mathrm{rpm}$ and $28^{\circ} \mathrm{C}$ for 2 days. Suspensions were centrifuged at $5,600 \times g$ at $20^{\circ} \mathrm{C}$ for $10 \mathrm{~min}$ and were resuspended in sterile distilled water before treatment of the plants.

\section{Plant material and growth conditions.}

A. thaliana ecotype Columbia (Col-0) was used as the wildtype control. The mutant lines used in this study are $f l s 2$ (Zipfel et al. 2004), bakl-4 (Chinchilla et al. 2007), mpk3 (Beckers et al. 2009), mpk6 (Beckers et al. 2009), wrky22 (GK-311E07.01), wrky 29 (GK-793H12.03), and efr-1 (Zipfel et al. 2006). All seeds were stored at $4^{\circ} \mathrm{C}$. A. thaliana seeds were sown in $9 \times 9 \times 10-\mathrm{cm}$ pots containing pasteurized soil mix of humus and perlite $(3: 1)$ and were maintained at $25^{\circ} \mathrm{C}$ with a 12 -h photoperiod at 60 to $70 \%$ relative humidity in a controlled-environment growth chamber. After 10 days, the plants were singled to plastic pots containing approximately $80 \mathrm{~cm}^{3}$ of pasteurized soil mix of humus and perlite $(3: 1)$.

\section{K165-V. dahliae bioassays.}

Eighteen-day-old plants were inoculated with K165 by root drenching, using $10 \mathrm{ml}$ of $1 \times 10^{8} \mathrm{CFU} / \mathrm{ml}$. After 5 days, the plants were challenge-inoculated with $V$. dahliae by root drenching with $10 \mathrm{ml}$ of a suspension of $1 \times 10^{7}$ conidia per milliliter of sterile distilled water (Tjamos et al. 2005). Control plants were mock-inoculated with $10 \mathrm{ml}$ of sterile distilled water. Disease severity at each observation was calculated from the number of leaves that showed wilting as a percentage of the total number of leaves of each plant and was periodically recorded for 25 days after inoculation. Disease ratings were plotted over time to generate disease progression curves. AUDPC was calculated by the trapezoidal integration method (Campbell and Madden 1990). Disease was expressed as a percentage of the maximum possible area for the whole period of the experiment, which is referred to as the relative AUDPC. The experiment was repeated two times with 30 plants per treatment and plant genotype (a total of 60 plants).

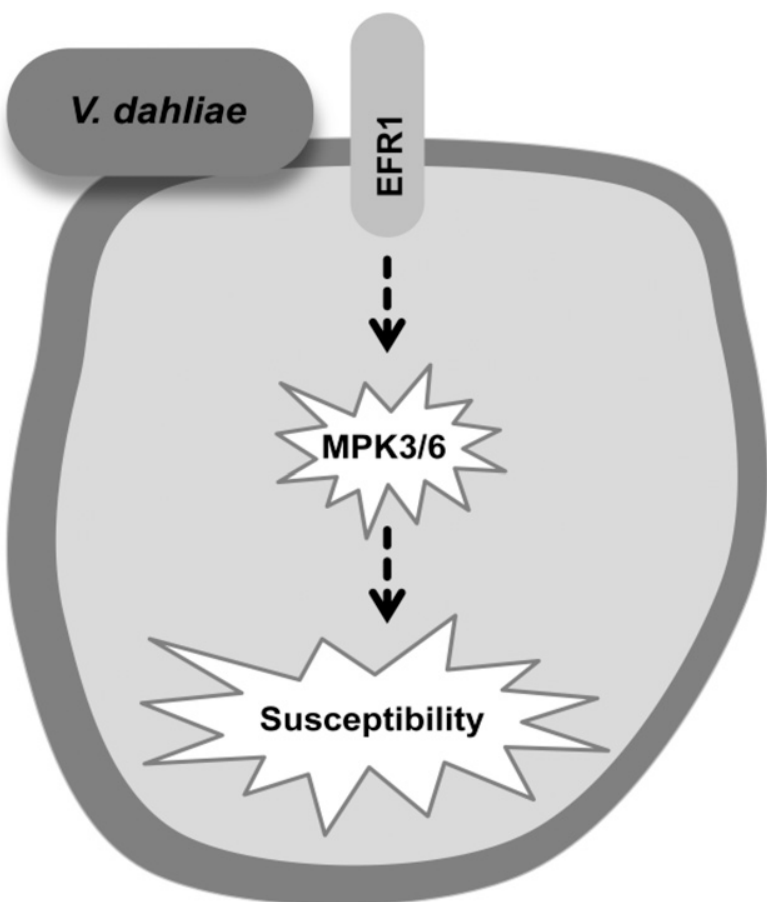

Fig. 7. Proposed model for a signaling pathway mediating Verticillium dahliae susceptibility. The efr $1, m p k 3$, and $m p k 6$ mutants showed resistance to $V$. dahliae colonization and symptom development. Therefore, it is suggested that $V$. dahliae hijacks EFR1, MPK3, and MPK6 to promote disease. 


\section{Rhizosphere population of K165.}

Colonization of the rhizosphere of wild-type and mutant plants by rifampicin-resistant K165 bacteria was determined at 10 and 20 days after the application of the bacterial strain. To estimate rhizosphere populations, $2 \mathrm{~g}$ of rhizosphere soil (soil particles in close contact with roots within a distance of approximately 1 to $5 \mathrm{~mm}$ ) was collected and shaken for $45 \mathrm{~min}$ in $50 \mathrm{mM}$ phosphate buffer, $\mathrm{pH} 7.0$, containing $0.02 \%$ Tween 20 , and the suspension was plated onto NAG medium supplemented with cycloheximide $(100 \mu \mathrm{g} / \mathrm{ml})$ and rifampicin $(100 \mu \mathrm{g} / \mathrm{ml})$. After $48 \mathrm{~h}$ of incubation at $28^{\circ} \mathrm{C}$, the number of bacterial CFU per gram of rhizosphere soil was determined.

The experiment was repeated three times with 15 replicates per experiment.

\section{DNA extraction and qPCR for fungal quantification.}

The aerial parts of 10 plants from each treatment were harvested for real-time qPCR analysis at 7 and $21 \mathrm{dpi}$. In brief, the aerial parts were cut at soil level, were pooled, were rinsed with sterile distilled water, and were ground to a fine powder, using an autoclaved mortar and pestle in the presence of liquid nitrogen.

Total DNA was isolated according to Dellaporta and associates (1983) and was quantified by spectrophotometry. qPCR assays for the quantification of $V$. dahliae were conducted as described previously by Fradin and associates (2011), using the primer pair ITS1-F 5'-AAAGTTTTAATGGTTCGCTAAGA-3' (Gardes and Bruns 1993) and ST-VE1-R 5'-CTTGGTCATTTA GAGGAAGTAA-3' (Lievens et al. 2006). qPCR was performed in a Stratagene Mx3005P thermocycler and, for the amplification reactions, QuantiFast SYBR Green PCR (Qiagen, Valencia, CA, U.S.A.) master mix was used. The results were analyzed with MxPro qPCR software.

For sample calibration, the Arabidopsis gene At4g26410, previously described as a stable reference gene (Czechowski et al. 2005), was targeted, using the primer pair $\mathrm{F} 5^{\prime}$-GAGCTGA AGTGGCTTCCATGAC-3' and R 5'-GGTCCGACATACCCA TGATCC-3'. PCR cycling started with an initial step of denaturation at $95^{\circ} \mathrm{C}$ for $5 \mathrm{~min}$, followed by 40 cycles of $95^{\circ} \mathrm{C}$ for $10 \mathrm{~s}$ and $60^{\circ} \mathrm{C}$ for $30 \mathrm{~s}$. PCR efficiency for each amplicon was calculated by employing the linear regression method on $\log$ (fluorescence) per cycle number data, using Lin-RegPCR software (Ramakers et al. 2003). The qPCR assays were performed in triplicates. The absence of nonspecific products and primer dimers was confirmed by the analysis of melting curves. The experiment was repeated two times with 10 plants per treatment and plant genotype (a total of 20 plants).

\section{Determination of transcript levels using reverse transcription-PCR assay.}

Aerial and root tissues, shortly rinsed with water to remove soil particles, were collected for RNA analysis. Samples were collected from 10 Col-0 plants per treatment (K165-, K165 + V. dahliae-, and V. dahliae- and mock-inoculated plants) at 3, 7, and $14 \mathrm{dpi}$ and were immediately frozen in liquid nitrogen and were stored at $-80^{\circ} \mathrm{C}$. For each sample, total RNA was extracted from $100 \mathrm{mg}$ of tissue ground with liquid nitrogen, using TRIzol reagent (Invitrogen, Paisley, U.K.) according to the manufacturer's instructions. The RNA samples were treated with DNase I (Invitrogen) to eliminate traces of contaminating genomic DNA. The RNA concentration was measured on a Nanodrop ND-1000 spectrophotometer (Saveen Werner, Malmö, Sweden). First-strand cDNA was synthesized, using SuperScript II (Invitrogen) following the manufacturer's procedure. For the amplification of PR1 (At2g19990), PDF1.2 (At5g44420), and $P R 2$ (At3g57260), the primer sets designed by Trusov and associates (2009) and Pantelides and associates (2010) were used. The qPCR assays were performed in triplicate. Normalization of gene expression, PCR efficiency, absence of nonspecific products and primer dimers, and data analysis were performed as described previously in the qPCR fungal quantification procedure. Under the experimental infection conditions, the gene expression of At4g26410, used for normalization of gene expression, was stable between treatments, with cycle threshold values equal to approximately 19.5. The experiment was repeated three times with 10 plants per treatment and plant genotype (a total of 30 plants).

\section{Statistics.}

Data on relative AUDPC, K165 rhizosphere population, $V$. dahliae DNA quantification, and gene expression were transformed with the $\sqrt{ } x+1$ transformation before analysis of variance was applied. When a significant $(P<0.05) \mathrm{F}$ test was obtained for treatments, data were subjected to means separation by Tukey's multiple range test.

\section{ACKNOWLEDGMENTS}

We thank T. Boller (University of Basel, Switzerland) for fls 2 seeds, C. Zipfel (The Sainsbury Laboratory, U.K.) for bak1-4 seeds, F. Mauch (University of Fribourg, Switzerland) for $e$ fr- 1 seeds and U. Conrath (RWTH Aachen University, Germany) for $m p k 3$ and $m p k 6$ seeds. Parts of this work were made possible by funds to J.-P. Métraux (University of Fribourg, Switzerland) from the Swiss National Science Foundation.

\section{LITERATURE CITED}

Arteca, R. N. 1995. Rooting. Pages 127-145 in: Plant Growth Substances. Principles and Applications. R. N. Arteca, ed. Chapman and Hall, New York. Asai, T., Tena, G., Plotnikova, J., Willmann, M. R., Chiu, W.-L., GomezGomez, L., Boller, T., Ausubel, F. M., and Sheen, J. 2002. MAP kinase signalling cascade in Arabidopsis innate immunity. Nature 415:977-983.

Beckers, G. J. M., Jaskiewicz, M., Liu, Y., Underwood, W. R., He, S. Y., Zhang, S., and Conrath, U. 2009. Mitogen-activated protein kinases 3 and 6 are required for full priming of stress responses in Arabidopsis thaliana. Plant Cell 21:944-953.

Bent, A. F., Innes, R. W., Ecker, J. R., and Staskawicz, B. J. 1992. Disease development in ethylene-insensitive Arabidopsis thaliana infected with virulent and avirulent Pseudomonas and Xanthomonas pathogens. Mol. Plant-Microbe Interact 5:372-378.

Campbell, C. L., and Madden, L. V. 1990. Introduction to plant disease epidemiology. Wiley, New York, USA.

Cecchini, E., Geri, C., Love, A. J., Coupland, G., Covey, S. N., and Milner, J. J. 2002. Mutations that delay flowering in Arabidopsis de-couple symptom response from cauliflower mosaic virus accumulation during infection. Mol. Plant Pathol. 3:81-90.

Chen, P., Lee, B., and Robb, J. 2004. Tolerance to a non-host isolate of Verticillium dahliae in tomato. Physiol. Mol. Plant Pathol. 64:283-291.

Chinchilla, D., Zipfel, C., Robatzek, S., Kemmerling, B., Nürnberger, T., Jones, J. D., Felix, G., and Boller, T. 2007. A flagellin-induced complex of the receptor FLS2 and BAK1 initiates plant defence. Nature 448:497-500.

Cronshaw, D. K., and Pegg, G. F. 1976. Ethylene as a toxin synergist in Verticillium wilt of tomato. Physiol. Plant Pathol. 9:33-44.

Czechowski, T., Stitt, M., Altmann, T., Udvardi, M. K., and Scheible, W. R. 2005. Genome-wide identification and testing of superior reference genes for transcript normalization in Arabidopsis. Plant Physiol. 139:5-17.

Dellaporta, S. L., Wood, J., and Hicks, J. B. 1983. A plant DNA minipreparation, version II. Plant Mol. Biol. Rep. 1:19-21.

Dietrich, R. A., Delaney, T. P., Uknes, S. J., Ward, E. R., Ryals, J. A., and Dangl, J. L. 1994. Arabidopsis mutants simulating disease resistance response. Cell 77:565-577.

Eynck, C., Koopmann, B., Grunewaldt-Stoecker, G., Karlovsky, P., and Von Tiedemann, A. 2007. Differential interactions of Verticillium longisporum and V. dahliae with Brassica napus detected with molecular and histological techniques. Eur. J. Plant Pathol. 118:259-274.

Fradin, E. F., Abd-El-Haliem, A., Masini, L., van den Berg, G. C. M., Joosten, M. H. A. J., and Thomma, B. P. H. J. 2011. Interfamily transfer of tomato Vel mediates Verticillium resistance in Arabidopsis. Plant Physiol. 156:2255-2265.

Fradin, E. F., and Thomma, B. P. H. J. 2006. Physiology and molecular aspects of Verticillium wilt diseases caused by V. dahliae and V. alboatrum. Mol. Plant Pathol. 7:71-86. 
Gardes, M., and Bruns, T. D. 1993. ITS primers with enhanced specificity for basidiomycetes-Application to the identification of mycorrhizae and rusts. Mol. Ecol. 2:113-118.

Glazebrook, J. 2005. Contrasting mechanisms of defense against biotrophic and necrotrophic pathogens. Annu. Rev. Phytopathol. 43:205-227.

Gómez-Gómez, L., and Boller, T. 2000. FLS2: An LRR receptor-like kinase involved in the perception of the bacterial elicitor flagellin in Arabidopsis. Mol. Cell 5:1003-1011.

Han, L., Li, G. J., Yang, K. Y., Mao, G., Wang, R., Liu, Y., and Zhang, S. 2010. Mitogen-activated protein kinase 3 and 6 regulate Botrytis cinereainduced ethylene production in Arabidopsis. Plant J. 64:114-127.

Heese, A., Hann, D. R., Gimenez-Ibanez, S., Jones, A. M., He, K., Li, J., Schroeder, J. I., Peck, S. C., and Rathjen, J. P. 2007. The receptor-like kinase SERK3/BAK1 is a central regulator of innate immunity in plants. Proc. Natl. Acad. Sci. U.S.A. 104:12217-12222.

Heinz, R., Lee, S. W., Saparno, A., Nazar, R. N., and Robb, J. 1998. Cyclical systemic colonization in Verticillium-infected tomato. Physiol. Mol. Plant Pathol. 52:385-396.

Horns, F., and Hood, M. E. 2012. The evolution of disease resistance and tolerance in spatially structured populations. Ecol. Evol. 2:1705-1711.

Hsu, F.-C., Chou, M.-Y., Chou, S.-J., Li, Y. R., Peng, H. P., and Shih, M.-C. 2013. Submergence confers immunity mediated by the WRKY22 transcription factor in Arabidopsis. Plant Cell 25:2699-2713.

Iavicoli, A., Boutet, E., Buchala, A., and Métraux, J. P. 2003. Induced systemic resistance in Arabidopsis thaliana in response to root inoculation with Pseudomonas fluorescens CHA0. Mol. Plant-Microbe Interact 16:851-858.

Johansson, A., Staal, J., and Dixelius, C. 2006. Early responses in the Arabidopsis-Verticillium longisporum pathosystem are dependent on NDR1, JA- and ET-associated signals via cytosolic NPR1 and RFO1. Mol. Plant-Microbe Interact 19:958-969.

Jones, J. D., and Dangl, J. L. 2006. The plant immune system. Nature 444: 323-329.

Joo, S., Seo, Y. S., Kim, S. M., Hong, D. K., Young Park, K. Y., and Kim, W. T. 2006. Brassinosteroid induction of AtACS4 encoding an auxinresponsive 1-aminocyclopropane-1-carboxylate synthase 4 in Arabidopsis seedlings. Physiol. Plant. 126:592-604.

Lee, S.-W., Nazar, R. N., Powell, D. A., and Robb, J. 1992. Reduced PAL gene suppression in Verticillium-infected resistant tomatoes. Plant Mol. Biol. 18:345-352

Li, G., Meng, X., Wang, R., Mao, G., Han, L., Liu, Y., and Zhang, S. 2012. Dual-level regulation of ACC synthase activity by MPK3/MPK6 cascade and its downstream WRKY transcription factor during ethylene induction in Arabidopsis. PLoS Genet. 8:e1002767.

Lievens, B., Brouwer, M., Vanachter, A. C. R. C., Cammue, B. P. A., and Thomma, B. P. H. J. 2006. Real-time PCR for detection and quantification of fungal and oomycete tomato pathogens in plant and soil samples. Plant Sci. 171:155-165.

Liu, Y., and Zhang, S. 2004. Phosphorylation of 1-aminocyclopropane-1carboxylic acid synthase by MPK6, a stress-responsive mitogen-activated protein kinase, induces ethylene biosynthesis in Arabidopsis. Plant Cell 16:3386-3399.

Lund, S. T., Stall, R. E., and Klee, H. J. 1998. Ethylene regulates the susceptible response to pathogen infection in tomato. Plant Cell 10:371-382.

Maniatis, T., Fritsch, E. F., and Sambrook, J. 1982. Molecular Cloning: A Laboratory Manual. Cold Spring Harbor Laboratory Press, Cold Spring Harbor, NY.

Millet, Y. A., Danna, C. H., Clay, N. K., Songnuan, W., Simon, M. D. Werck-Reichhart, D., and Ausubel, F. M. 2010. Innate immune responses activated in Arabidopsis roots by microbe-associated molecular patterns. Plant Cell 22:973-990.

Mishina, T. E., and Zeier, J. 2007. Pathogen-associated molecular pattern recognition rather than development of tissue necrosis contributes to bacterial induction of systemic acquired resistance in Arabidopsis. Plant J. 50:500-513.

Mur, L. A. J., Kenton, P., Atzorn, R., Miersch, O., and Wasternack, C. 2006 The outcomes of concentration-specific interactions between salicylate and jasmonate signaling include synergy, antagonism, and oxidative stress leading to cell death. Plant Physiol. 140:249-262.

O’Donnell, P. J., Jones, J. B., Antoine, F. R., Ciardi, J., and Klee, H. J. 2001. Ethylene-dependent salicylic acid regulates an expanded cell death response to a plant pathogen. Plant J. 25:315-323.

Pang, Y., Liu, X., Ma, Y., Chernin, L., Berg, G., and Gao, K. 2009. Induction of systemic resistance, root colonisation and biocontrol activities of the rhizospheric strain of Serratia plymuthica are dependent on $\mathrm{N}$-acyl homoserine lactones. Eur. J. Plant Pathol. 124:261-268.

Pantelides, I. S., Tjamos, S. E., and Paplomatas, E. J. 2010. Ethylene perception via ETR1 is required in Arabidopsis infection by Verticillium dahliae. Mol. Plant Pathol. 11:191-202.
Pegg, G. F. 1976. The response of ethylene-treated tomato plants to infection by Verticillium albo-atrum. Physiol. Plant Pathol. 9:215-226.

Pegg, G. F. 1981. Biochemistry and physiology of pathogenesis. Pages 193-253 in: Fungal Wilt Diseases of Plants. M. E. Mace, A. A. Bell, and C. H. Beckman, eds. Academic Press, New York.

Pegg, G. F., and Brady, B. L. (eds.) 2002. Verticillium Wilts. CABI Publishing, New York.

Pieterse, C. M. J., van Wees, S. C. M., van Pelt, J. A., Knoester, M., Laan, R., Gerrits, H., Weisbeek, P. J., and van Loon, L. C. 1998. A novel signaling pathway controlling induced systemic resistance in Arabidopsis. Plant Cell 10:1571-1580.

Pilloff, R. K., Devadas, S. K., Enyedi, A., and Raina, R. 2002. The Arabidopsis gain-of-function mutant dll1 spontaneously develops lesions mimicking cell death associated with disease. Plant J. 30:61-70.

Pozo, M. J., Van Der Ent, S., Van Loon, L. C., and Pieterse, C. M. J. 2008. Transcription factor MYC2 is involved in priming for enhanced defense during rhizobacteria-induced systemic resistance in Arabidopsis thaliana. New Phytol. 180:511-523.

Ramakers, C., Ruijter, J. M., Deprez, R. H., and Moorman, A. F. 2003 Assumption-free analysis of quantitative real-time polymerase chain reaction (PCR) data. Neurosci. Lett. 339:62-66.

Robb, J., Lee, B., and Nazar, R. N. 2007. Gene suppression in a tolerant tomato-vascular pathogen interaction. Planta 226:299-309.

Robison, M. M., Shah, S., Tamot, B., Pauls, K. P., Moffatt, B. A., and Glick, B. R. 2001. Reduced symptoms of Verticillium wilt in transgenic tomato expressing a bacterial ACC deaminase. Mol. Plant Pathol. 2:135-145.

Roux, M., Schwessinger, B., Albrecht, C., Chinchilla, D., Jones, A., Holton, N., Malinovsky, F. G., Tör, M., de Vries, S., and Zipfel, C. 2011. The Arabidopsis leucine-rich repeat receptor-like kinases BAK1/SERK3 and BKK1/SERK4 are required for innate immunity to hemibiotrophic and biotrophic pathogens. Plant Cell 23:2440-2455.

Schikora, A., Schenk, S. T., Stein, E., Molitor, A., Zuccaro, A., and Kogel, K.-H. 2011. $N$-acyl-homoserine lactone confers resistance toward biotrophic and hemibiotrophic pathogens via altered activation of AtMPK6. Plant Physiol. 157:1407-1418.

Schuhegger, R., Ihring, A., Gantner, S., Bahnweg, G., Knappe, C., Vogg, G., Hutzler, P., Schmid, M., Van Breusegem, F., Eberl, L., Hartmann, A., and Langebartels, C. 2006. Induction of systemic resistance in tomato by $\mathrm{N}$ acyl-L-homoserine lactone-producing rhizosphere bacteria. Plant Cell Environ. 29:909-918.

Schulze, B., Mentzel, T., Jehle, A. K., Mueller, K., Beeler, S., Boller, T., Felix, G., and Chinchilla, D. 2010. Rapid heteromerization and phosphorylation of ligand-activated plant transmembrane receptors and their associated kinase BAK1. J. Biol. Chem. 285:9444-9451.

Schwessinger, B., and Zipfel, C. 2008. News from the frontline: Recent insights into PAMP-triggered immunity in plants. Curr. Opin. Plant Biol. 11:389-395.

Shan, L., He, P., Li, J., Heese, A., Peck, S. C., Nürnberger, T., Martin, G. B., and Sheen, J. 2008. Bacterial effectors target the common signaling partner BAK1 to disrupt multiple MAMP receptor-signaling complexes and impede plant immunity. Cell Host Microbe 4:17-27.

Sinha, A. K., and Wood, R. K. S. 1968. Studies on the nature of resistance in tomato plants to Verticillium albo-atrum. Ann. Appl. Biol. 62:319-327.

Tateda, C., Zhang, Z., Shrestha, J., Jelenska, J., Chinchilla, D., and Greenberg, J. T. 2014. Salicylic acid regulates Arabidopsis microbial pattern receptor kinase levels and signaling. Plant Cell 26:4171-4187.

Thaler, J. S., Owen, B., and Higgins, V. J. 2004. The role of the jasmonate response in plant susceptibility to diverse pathogens with a range of lifestyles. Plant Physiol. 135:530-538.

Tintor, N., Ross, A., Kanehara, K., Yamada, K., Fan, L., Kemmerling, B., Nürnberger, T., Tsuda, K., and Saijo, Y. 2013. Layered pattern receptor signaling via ethylene and endogenous elicitor peptides during Arabidopsis immunity to bacterial infection. Proc. Natl. Acad. Sci. U.S.A. 110:6211-6216

Tjamos, E. C., Tsitsigiannis, D. I., Tjamos, S. E., Antoniou, P. P., and Katinakis, P. 2004. Selection and screening of endorhizosphere bacteria from solarized soils as biocontrol agents against Verticillium dahliae of solanaceous hosts. Eur. J. Plant Pathol. 110:35-44.

Tjamos, S. E., Flemetakis, E., Paplomatas, E. J., and Katinakis, P. 2005. Induction of resistance to Verticillium dahliae in Arabidopsis thaliana by the biocontrol agent K-165 and pathogenesis-related proteins gene expression. Mol. Plant-Microbe Interact 18:555-561.

Ton, J., Van Pelt, J. A., Van Loon, L. C., and Pieterse, C. M. J. 2002. Differential effectiveness of salicylate-dependent and jasmonate/ethylene-dependen induced resistance in Arabidopsis. Mol. Plant-Microbe Interact 15:27-34.

Trusov, Y., Sewelam, N., Rookes, J. E., Kunkel, M., Nowak, E., Schenk, P. M., and Botella, J. R. 2009. Heterotrimeric G proteins-mediated resistance to necrotrophic pathogens includes mechanisms independent 
of salicylic acid-, jasmonic acid/ethylene- and abscisic acid-mediated defense signaling. Plant J. 58:69-81.

Tsuda, K., Sato, M., Glazebrook, J., Cohen, J. D., and Katagiri, F. 2008. Interplay between MAMP-triggered and SA-mediated defense responses. Plant J. 53:763-775.

van Hulten, M., Pelser, M., van Loon, L. C., Pieterse, C. M. J., and Ton, J. 2006. Costs and benefits of priming for defense in Arabidopsis. Proc. Natl. Acad. Sci. U.S.A. 103:5602-5607.

Veronese, P., Narasimhan, M. L., Stevenson, R. A., Zhu, J. K., Weller, S. C., Subbarao, K. V., and Bressan, R. A. 2003. Identification of a locus controlling Verticillium disease symptom response in Arabidopsis thaliana. Plant J. 35:574-587.

Wang, X., Kota, U., He, K., Blackburn, K., Li, J., Goshe, M. B., Huber, S. C., and Clouse, S. D. 2008. Sequential transphosphorylation of the BRI1/BAK1 receptor kinase complex impacts early events in brassinosteroid signaling. Dev. Cell 15:220-235.
Yun, H. S., Bae, Y. H., Lee, Y. J., Chang, S. C., Kim, S. K., Li, J., and Nam, K. H. 2009. Analysis of phosphorylation of the BRI1/BAK1 complex in arabidopsis reveals amino acid residues critical for receptor formation and activation of BR signaling. Mol. Cells 27:183-190.

Zhang, Y., Wang, X. F., Ding, Z. G., Ma, Q., Zhang, G. R., Zhang, S. L., Li, Z. K., Wu, L. Q., Zhang, G. Y., and Ma, Z. Y. 2013. Transcriptome profiling of Gossypium barbadense inoculated with Verticillium dahliae provides a resource for cotton improvement. BMC Genomics 14:637.

Zipfel, C. 2008. Pattern-recognition receptors in plant innate immunity. Curr. Opin. Immunol. 20:10-16.

Zipfel, C., Kunze, G., Chinchilla, D., Caniard, A., Jones, J. D. G., Boller, T., and Felix, G. 2006. Perception of the bacterial PAMP EF-Tu by the receptor EFR restricts Agrobacterium-mediated transformation. Cell 125:749-760.

Zipfel, C., Robatzek, S., Navarro, L., Oakeley, E. J., Jones, J. D. G., Felix, G., and Boller, T. 2004. Bacterial disease resistance in Arabidopsis through flagellin perception. Nature 428:764-767. 